\title{
The determinants of self-employment of black entrepreneurs in Ladysmith, KwaZulu-Natal
}

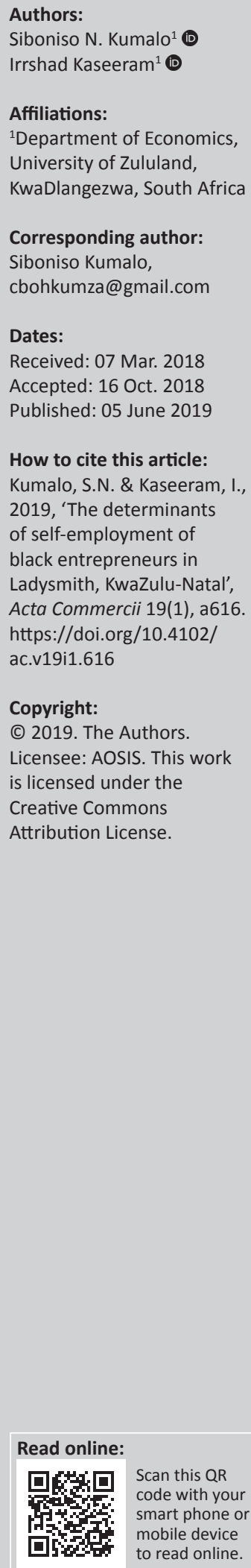

Orientation: The study seeks to provide an in-depth understanding of the determinants of self-employment within the context of black entrepreneurs.

Research purpose: Given the unprecedented increase in self-employment, because of reduction in formal job opportunities in South Africa, the primary objective of this study was to probe the determinants of self-employment relative to being a wage earner among black people in Ladysmith.

Motivation for the study: The study investigated the determinants of self-employment through the use of the logistic modelling technique as its primary focus.

Research design, approach and method: The study employed both probability and nonprobability sampling techniques. The convenience and snowball sampling methods were used to locate all targeted entrepreneurs while the systematic random sampling method was used to locate the wage earners. A total of 450 respondents were interviewed through face-to-face administered questionnaires. The data collected was statistically analysed, using SPSS to acquire the descriptive statistics and EViews software to obtain logistic regression results and the related diagnostic tests (Hosmer-Lemeshow test and Wald statistics).

Main findings: All the variables, except for household income per capita, were statistically significant, indicating that they were plausible predictors of self-employment.

Practical/managerial implications: Financial life skills and entrepreneurship training ought to be embedded in all learning programmes at the primary, secondary and tertiary levels. In particular, all young persons through whatever skills development programme - including those offered at in-service and/or work-related training - they are given access to, must be taught to develop an entrepreneurial mind-set.

Contribution/value-add: A combination of skills development and guidance-based access to finance to targeted groups involving women, the young adults at schools and tertiary institutions and entrepreneurial adults are likely to reap significant outcomes.

Keywords: self-employment; wage earner; logistic; black entrepreneurs; KwaZulu-Natal.

\section{Introduction}

Faced with the endemic socio-economic diseases of poverty, inequality and unemployment, self-employment seems to be the only way out for unemployed South Africans. Severe global economic crises brought on by the 2008 credit crunch, the slowdown in the Chinese economic growth rate as well as internal political and policy risks that South Africa faces have led to a reduction in its growth potential, which makes it difficult for one to secure a job in the formal sector. In this study, 'self-employed' refers to those individuals who seek their own work opportunities rather than being provided with work by an employer; thus they earn income from practising a trade or operating a business. The study only considers small, medium and micro registered businesses.

Note that globally, the number of individuals who became self-employed recently has increased tremendously; hence the self-employment phenomenon has received much literature attention, especially in developed countries like the USA, China and Asian countries. However, not much literature has been dedicated to exploring this phenomenon in other African countries, specifically in South Africa (Banerjee, Duflo \& Glennerster 2008; Gordon 2010; Herrington, Kew \& Kew 2009). This study seeks to investigate the determinants of black self-employment in Ladysmith and analyse the individual choices between wages and self-employment. 
Ladysmith is a small town surrounded by the Drakensberg Mountains in the uThukela District, which is located $365 \mathrm{~km}$ from Johannesburg and $230 \mathrm{~km}$ from Durban, within the KwaZulu-Natal Province. The town is known for food processing, manufacturing and tyre industries but currently it is facing increasing unemployment rates among the youth.

Empirical evidence teaches us that gainful employment in the formal sector alone cannot eradicate unemployment (Allen et al. 2008). According to the Global Entrepreneurial Monitor (GEM) report (GEM 2012), sub-Saharan Africa's gross domestic product rose to $4.9 \%$ from 2000 to 2008 because of new opportunities, innovation and increased employment created by entrepreneurship. Furthermore, at a regional level, Africa has the smallest proportion of nonhiring entrepreneurs on average at about 33\% (GEM 2016).

Total early-stage entrepreneurial activity (TEA), which measures the percentage of adults (18-64) who have been running newly established businesses that are under 3 years old, depicts that among the efficiency-driven economies, TEA rates are typically highest in Africa, Latin America and the Caribbean. The TEA rates in South Africa increased to $10.6 \%$ in 2013, decreased in 2014 to $7 \%$, increased in 2015 to $9.2 \%$ and decreased to $7 \%$ in 2016 (GEM 2016).

Furthermore, reports by the Companies and Intellectual Property Commission (CIPC 2016), South African Revenue Services (SARS 2015/2016) and StatsSA (2015/2016) depict an increasing trend in self-employment. The report by CIPC (2016) revealed that, in the period 2008-2009, 27358 companies, 261065 close corporations and 6504 co-operatives were registered.

Moreover, a total of 289296 entities were registered in 2009-2010, 215561 in 2010-2011, 243661 in 2012-2013, 262111 in 2013-2014, 257069 in 2014-2015 and 331354 in 2015-2016 (CIPC 2016). What factors result in these individuals choosing to be self-employed? This paper attempts to address this question.

The Organisation for Economic Co-operation and Development (OECD 2013) observed that much effort by national government, through introducing a simplified business registration process, training and access to financial capital and trying to motivate people to start their companies, resulted in self-employment. The South African government, through the Department of Trade and Industry and through the new Ministry of Small Business Development, has provided various incentives targeting largely black emerging and established entrepreneurs to create new enterprises because they create new jobs, reduce unemployment, stimulate competition, efficiency and innovation and contribute to economic growth (Allen et al. 2008; Bosma \& Levie 2010; Maas \& Herrington 2006). This study therefore seeks to investigate the determinants of self-employment relative to being a wage earner in Ladysmith.
This study will commence by outlining the literature review highlighting the theoretical and empirical evidence underpinning the study, followed by the problem statement, objectives of the study, research methodology, interpretation of the results and lastly the conclusion of the study.

\section{Literature review}

The self-employment phenomenon has been widely investigated in developed countries and a number of factors have been discovered as the determinants of self-employment. These factors can either be grouped as pecuniary benefits, which focus on financial gain, or non-pecuniary benefits, which include both social and psychological factors that influence the career choice. For the purpose of this study, the literature review will focus on both pecuniary and non-pecuniary factors.

The literature review of this study focuses on variables that are considered to be crucial in explaining self-employment, including education, age, per capita income based on household income, networks and family business background, marital status, gender, risk propensity and lastly access to finance.

\section{Education}

According to Unger et al. (2011) and Livanos (2009), education plays a fundamental role in determining self-employment. However, other studies that probed the determinants of selfemployment have produced inconclusive results with regards to the effects of educational attainment on self-employment. Research like that of Elert, Andersson and Wennberg (2015), Humphries (2017), Van Praag, Witteloostuijn and Sluis (2013) and Koellinger (2008) suggests that education contributes greatly to the likelihood of professional self-employment.

They argue that education provides an individual with the necessary skills and insights into what is needed to run a successful business. Humphries (2017) investigated the causes and consequences of self-employment over the life cycle and pointed out that cognitive skills, education and prior work experience are important determinants of the types of businesses individuals start, how many workers they employ and how long they remain in self-employment. Humphries argues that education provides individuals with key skills they need to start a business.

On the other hand, Joona and Wadensjö (2011) add that it is unlikely for an educated person to become self-employed because the market pays competitive rates for skilled individuals or professionals. Investigating ethnicity and entrepreneurship in the USA to try to explain racial and ethnic group variations in self-employment, Butler and Herring (1991) found that increasing levels of education did not influence the probability of being self-employed for black people. They contend that the significant relationship only applies to white people. African Americans who are 
highly educated are more likely to work at salaried jobs in big organisations to take advantage of high earnings, stable jobs and retirement benefits.

\section{Age}

Empirically, the relationship between age and self-employment is not clear, as literature available on the subject yield two strands. The first strand suggests that there exists a positive and significant relationship between self-employment and age, depicting that self-employment is more likely to be undertaken by older people (Halvorsen \& Howell 2017; Stefanovic \& Stosic 2012).

According to Kibler et al. (2015), Kautonen, Luoto and Tornikoski (2010), Schjoedt, Renko and Shaver (2014) and Orth, Trzesniewski and Robins (2010), age reflects the wealth of an individual; therefore, when individuals are older, they have enough wealth to use to start a business. Halvorsen and Howell (2017) note that older adults consistently have a higher rate of self-employment than their younger counterparts, and the rates of self-employment among workers continue to rise as age increases from the 'young old' to the 'old old'.

By contrast, the second strand suggests that given the incentives by government to promote self-employment among the youth, self-employment is highly likely to be undertaken by younger people. Furthermore, Minola, Criaco and Obschonka (2015) note that policymakers deem the promotion of entrepreneurship and self-employment a useful tool to 'fight' youth unemployment.

This view is supported by the findings of Arenius and Minniti (2005) using samples from Mexico to the UK, which suggested that younger people are more prone to being self-employed as opposed to older ones. Hence there are mixed findings regarding age as an influence on self-employment.

\section{Family business background}

Among the major determinants of self-employment relative to gainful employment is the family background and the contacts the family or individual have. Family background has an impact on one's career decision, as young family members tend to follow in the footsteps of those before them.

Joona and Wadensjö (2011), Steier (2007) and Goduscheit (2011) propound that one's family background plays a key role in establishing a lifelong motivation to run one's own business. This can be achieved through the transfer of information and knowledge, capital and networks the parents have already established in the business sector. Investigating Korean businesses in the USA, Yoon (1997) found that networks and contacts in business play an important role in pushing one to be self-employed. He argues that family networks open business doors that would otherwise be difficult to open.

\section{Gender}

According to studies such as those by Eddleston and Powel (2012) and Henley (2009), gender plays a fundamental role in occupational choice. According to Livanos (2009), males are more likely to be self-employed than women. Encoring the findings of Arenious and Minniti (2005) advocate that chances of women becoming self-employed are very slim compared to men. Contrary to these findings, Georgellis and Wall (2005) advocate that women are more likely to become self-employed because of being discriminated against in formal employment or because of high rates of unemployment among women.

\section{Marital status}

The effect of marital status towards occupational choice have been widely documented by several scholars such as Fairlie and Meyer (1996) and Livanos (2009), who contended that marital status plays a crucial role in determining occupational choice. However, there is more ambiguity about the effect of marital status on transition to self-employment as prior studies present inconclusive results pertaining to the individual's occupational choice.

According to Fairlie and Meyer (1996), Budig (2006) and Livanos (2009), married people are more likely to be selfemployed than single people. They attributed this to the fact that marriage grants stability, thereby reducing the inherent risk associated with self-employment. Parker (2005) looked at entrepreneurship among married couples in the USA using a probit model and found that, because of the knowledge the other partner has, the chances of both of them forming a company together are very high.

\section{Household income per capita}

Among the key factors that influence occupational choice is household income per capita. Numerous studies propound that occupational choice is highly motivated by earnings (Bargain \& Kwenda 2009; Preisendörfer, Bitz \& Bezuidenhout 2011).

Clark and Drinkwater (2000) suggest that the difference between an individual's predicted earnings in paid employment and self-employment exert a powerful influence upon the employment choice. According to Hamilton, (2000) earnings are the most important aspect to job satisfaction of an employee. The decision to be self-employed or work for organisations will depend largely on the earnings each offers.

According to Taylor (1999), self-employment offers higher earnings compared to gainful employment. Preisendörfer et al. (2011) note that people become self-employed because they want to stand on their own to better their standard of living, autonomy and have status as entrepreneurs who are perceived to be earning high incomes. Ruffer and Knight (2007) assert that, because of low wages and inadequate family benefits earned in gainful employment, individuals 
will want to earn higher earnings in the self-employed sector. Contrary to this view, Bargain and Kwenda (2009) contend that because of stringent labour market regulations such as minimum wage and higher unionisation in the formal sector, which often bargain for higher wages, the gainfully employed earn more than those in self-employment.

\section{Problem statement}

Small and medium-sized business development has been an issue in development economics for a long time. Debates have been staged, studies have been conducted (Gordon 2010; Halvorsen \& Howell 2017; Joona and Wadensjö 2011; Schjoedt et al. 2014) and all suggest that because of failure of the large formal sector to facilitate economic growth and employment creation, small and medium-sized enterprises are the key to attaining the desired economic growth.

It is of paramount importance to understand the policy implications of self-employment such as that adopted in 1996, which seeks to promote black-owned businesses through financing them, as they have the potential to eradicate unemployment.

Given the high national unemployment rate of $25.2 \%(43.4 \%$ in Ladysmith), of which $45 \%$ is youth, job creation becomes the central focus of economic policy (Ladysmith Chamber of Commerce [LCC] 2016; StatsSA 2017). Furthermore, because the formal sector cannot absorb every unemployed person, self-employment becomes the next best option.

A vast amount of empirical evidence assert that because of economic recession and declining economic growth, selfemployment rates increase tremendously. However, there are serious gaps in the literature in regard to the determinants of self-employment. This study seeks to investigate the determinants of black self-employment and analyse individual choices between gainful employment and self-employment.

\section{Research objective}

Given the unprecedented increase in self-employment in South Africa, the primary objective of this study was to probe the determinants of self-employment among black people in Ladysmith. While addressing the primary objective, the secondary objectives were to analyse individual choice between gainful employment and self-employment, as well as other factors leading to choice of self-employment.

\section{Research methodology}

This section describes the sampling techniques that was employed when collecting the data from black entrepreneurs and the gainfully employed in Ladysmith. Additionally, this section elucidates the procedures used in designing the instrument and data collection. Furthermore, an outline of the essential elements of the logistic regression model, which includes a detailed description of the dichotomous dependent variable (self-employed vs. wage earner) and the explanatory variables considered, are explained. Finally, the model validation and diagnostic tests, which include the Wald statistic and Hosmer-Lemeshow (HL) tests, are briefly discussed in this section.

\section{Demographic information}

The study probes the determinants of self-employment among black entrepreneurs in Ladysmith, South Africa. Ladysmith is a small town surrounded by the Drakensberg Mountains in the uThukela District between Johannesburg $(365 \mathrm{~km})$ and Durban $(230 \mathrm{~km})$ in KwaZulu-Natal Province. Ladysmith comprises rural, semi-rural and urban areas within which black businesses are operating. According to the StatsSA (2011), the town has a total population of 237437 , of which $73.3 \%$ are black Africans, 2.9\% mixed race, $15 \%$ Indians, $8.3 \%$ white people and $0.5 \%$ other. Furthermore, the town is experiencing high rates of unemployment (43.40\%) among youth between ages 18 and 35 (ELM 2015/16).

\section{Sampling and data collection}

For the purpose of this study, both probability and nonprobability sampling techniques were employed. The study targeted both areas where a majority of black businesses operated as well as the central business district, where entrepreneurs of all races owned businesses. The convenience and snowball sampling methods were used to locate all targeted entrepreneurs in areas within wards where black businesses were quite scattered; while using this approach the study attempted to be exhaustive, where every known registered black business was contacted, with the response rate being $64 \%$. The systematic random sampling method was used to locate the gainfully employed within 27 of the most populous residential wards in Ladysmith. The main roads of the targeted areas were randomly selected and every fifth street was chosen. In each selected street, every third house was selected for interview and in case they were not interested in participating, as highlighted in the instruction of the questionnaires, the next house was selected, and the sequence was maintained.

In this study, a sample of 450 was interviewed through faceto-face administered questionnaires. There were two sets of questionnaires, one written in English and second written in isiZulu, as Ladysmith is dominated by Zulu-speaking people. Those who were comfortable with English even though they were Zulu speaking were given English questionnaires. From the 450 interviewed, $33.6 \%$ were self-employed and $66.4 \%$ were gainfully employed. The study only considered those in self-employment for longer than a year.

The data collection process started on 02 October 2014 in Ladysmith. The data was first collected in the urban areas, which included Mkhamba Gardens and other secondary commercial areas including Limit Hill, Hospital Park, Accaicaville, Ezakheni and Tsakane. Moreover, data was collected in rural areas including Roosboom, Watersmeet and Blue Bank. 


\section{Ethical considerations}

Ethical clearance was obtained from the research ethics committee of the University of Zululand (clearance number: UZREC 171110-030-RA LEVEL 01 PGM 2014/113).

\section{Statistical analysis}

The data collected was statistically analysed, using SPSS and EViews. SPSS was utilised to acquire the descriptive statistics while EViews was used to run the logistic regression including the diagnostic tests (HL test and Wald statistic).

\section{The logistic model}

The study investigated the determinants of self-employment through the use of the logistic modelling technique as its primary focus. The use of the logistic model in this study was to predict the probability of being self-employed relative to being a wage earner in Ladysmith, KwaZulu-Natal. In this study self-employment was modelled as a dichotomous variable: if the person was self-employed the variable was coded as 1 and if the person was a wage or salary earner the variable was coded as 0 . The logistic model enabled the researcher to assess what set of factors increases the probability of the dependent variable taking on a value of 1 (i.e. becoming self-employed).

The logistic regression model can be expressed mathematically as follows:

$\ln \left(\frac{P_{\mathrm{i}}}{1-P_{\mathrm{i}}}\right)=\beta_{0}+\beta_{1} x_{1 i}+\beta_{2} x_{2 i}+\beta_{3} x_{3 i} \ldots, \ldots,+\beta_{k} x_{k \mathrm{i}}$

Where $\left(Y_{i}=1\right)=1-P\left(Y_{i}=0\right)$,

$P\left(Y_{i}=1\right),\left(Y_{i}=0\right)$ is the probability of being self-employed and gainfully employed of an observation $i$, respectively.

$\beta_{0}=\log$ odds when all $x_{i i}$ are 0

$\beta_{j}=$ increase in log odds when $x_{j i}$ is increased by one unit, $j=1, \ldots, k$

$e^{\beta} j=$ increase in odds when $x_{j i}$ is increased by one unit, $j=1, \ldots, K$

In this study the logistic model considered the log odd $\operatorname{Ln}\left(p_{i} / 1-p_{i}\right)$ of a person being self-employed as a function of a set of independent variables. The coefficients in the logit model register the effect on the log odds of a little change in the independent variables (Al-Ghamdi 2001).

In the quest to understand the multiple macro and micro factors that contribute to one choosing to be self-employed over being gainfully employed, the study explored several variables. The study explored these factors because of the possibility that they may enhance or decrease the possibility of one choosing to be self-employed over being a wage earner. In order to analyse the detailed effect of different variables on self-employment, a logistic regression model was developed.
The logistic regression model includes all the variables of interest based on the theoretical and empirical evidence underpinning the study. This model mathematically can be expressed as follows:

$$
\begin{aligned}
\ln \left(\frac{p i}{1-p i}\right)= & \beta_{1}+\beta_{2} E D U+\beta_{3} A G E+\beta_{4} G E N+\beta_{5} H I P+ \\
& \beta_{6} M S+\beta_{7} A R+\beta_{8} F B B+\beta_{9} A C+\mu_{i}
\end{aligned}
$$

where:

$L n$ is the natural logarithm.

$P_{i}$ is the probability that event $Y_{i}=1$, which is self-employment, occurs as a result of the $X_{i}$ factors.

$1-P_{i}$ is the probability that event $Y_{i}=0$ occurs or alternatively, $Y_{i} \neq 1$ does not occur, which then implies that the individual is gainfully employed.

$\beta_{1}=$ is the coefficient of the constant term.

Table 1 provides a summarised account of all the variables used in the logistic regression models together with the coding that was used in the study.

\section{Descriptive results and discussion}

The results of this study will be discussed in two parts. The first part focuses on the descriptive statistics and the second part is the discussion of the logistic regression results.

With regards to how the sample was distributed throughout the two different occupation categories, namely self-employed and gainfully employed, the descriptive analysis shows that the gainfully employed dominated the sample, constituting $66.4 \%$ of the total sample, and only $33.4 \%$ were self-employed.

The descriptive statistics show that from the self-employed participants, $40.4 \%$ were females and $59.6 \%$ were males. Out of the 299 gainfully employed, $51.5 \%$ were females and $48.5 \%$ were male participants.

Pertaining to the age of the respondents, the descriptive statistics show that, though the margin is very small, the majority of the participants $(33.8 \%)$ were between the ages of 18 and 30 years old, followed by both the age group between 31 and 38 years old, accounting for $33.1 \%$, and the age group

\begin{tabular}{|c|c|}
\hline Variables & Description of variables \\
\hline \multicolumn{2}{|l|}{ Dependent variable } \\
\hline $\boldsymbol{P}_{i}$ (occupation) & $1=$ self-employment; 0 = gainfully employed \\
\hline \multicolumn{2}{|l|}{ Explanatory variables } \\
\hline Age & $\begin{array}{l}\text { Binned into three categories: } 1=\text { less than } 30 \\
2=31-38 ; 3=39+\end{array}$ \\
\hline Gender & $1=$ female $; 0=$ male \\
\hline Education & Number of years in school \\
\hline $\begin{array}{l}\text { Household income per } \\
\text { capita (monthly) }\end{array}$ & $\begin{array}{l}1=R 0-R 800 ; 2=R 800-R 1500 ; 3=R 1500-R 3000 ; \\
4=R 3000-R 5000 ; 5=R 5000-R 10000 ; \\
6=R 10000-R 20000 ; 7=R 20000+\end{array}$ \\
\hline Marital status & $1=$ married $; 0=$ other \\
\hline Family business background & $1=$ yes $; 0=$ no \\
\hline Access to finance & $1=$ yes $; 0=$ no \\
\hline$\mu_{i}$ & Error term \\
\hline
\end{tabular}

TABLE 1: Summary of variables used in the logistic model. 
of 39 and above, accounting for $33.1 \%$ as well. Studying age by gender involvement between these two occupations, the descriptive statistics show that $34 \%$ of total females were between the ages of 18 and 30,37.7\% were between 31 and 38 years old and the remaining $28.45 \%$ were 39 and above. Consequently, $33.6 \%$ of the male participants were between the ages of 18 and 30 years, $28.9 \%$ between 31 and 38 years and lastly $37.4 \%$ were 39 and above.

Pertaining to marital or cohabitation status, it is worth noting that from the total sample of 450 participants, $43.8 \%$ were married or living together (included in this category were also those who were widowed or separated after their self-employment decision occurred) and 56.2\% were single (included in this category where those who were divorced or widowed before the self-employment endeavour resulted). Respondents were asked if they were separated, divorced or widowed before the self-employment decision occurred; if the answer was 'no' then they were classed in the marital context; hence they were coded as 1 , that is, married. If they were continuously single or were divorced, separated or widowed before the decision to become self-employed then they were classed as 0 . In order to ensure that the variable was not misinterpreted, additionally the respondents were asked to confirm whether the marital or cohabitation relationship assisted in them becoming self-employed.

Studying marital status by gender involvement, the results show that $39.5 \%$ of all female participants were married and $60.5 \%$ fell into the category of single. Out of 235 male participants, $47.7 \%$ were married and $52.3 \%$ single.

The instrument used to gather the data explicitly asked the respondent to provide the total monthly household income in South African Rand(R), as well as inter alia the household size. This data was used to calculate per capita income per month by dividing the total household income by household size. Because of the wide variation in per capita household income, the researchers out of convenience chose the selected categories appearing in Table 2.

The descriptive statistics showed that from the income category of R0-R800, there were no female-headed households earning R800 or below, whereas only three maleheaded households fell in this category. Of participants whose per capita earning was between R800 and R1500, only nine were female-headed households and two were male-headed households. From the group earning between R1500 and R3000, one participant was a female and nine were male-headed households. Furthermore, the descriptive statistics revealed that out of the $19.8 \%$ earning between R3000 and R5000, 43 were female-headed households and 46 were males. From those who earned between R5000 and R10 000 (25.6\%), only 59 were female-headed households and 56 were male-headed households. It is also worth noting that out of the $32.7 \%$ earning between R10 000 and R20 000, 71 were female-headed households and 76 were male-headed households. And lastly, out of the $16.7 \%$ earning R20 000 or more, 32 were female-headed households and 43 were male-headed households.

This study also considered if the participants had any family business background. The results of the descriptive statistics depicted that out of the total sample of 450 , only $31.3 \%$ did not have any family business background whereas the majority $(68.7 \%)$ of the participants had family business background. In the female participants, $73.5 \%$ had family business background while only $26.5 \%$ of females did not have family business background. Only $64.3 \%$ of male participants confirmed having business background whereas the remaining $35.7 \%$ did not have family business background.

Confirming prior expectations, only $20.7 \%$ of the participants had access to finance, whereas the remaining $79.3 \%$ confirmed the view that access to finance is a great challenge. Of the female participants, $80.5 \%$ acknowledged that they did not have access to finance, while only $19.5 \%$ female had access to finance. Of the total male participants, $78.3 \%$ did not have access to finance and only $21.7 \%$ had funding. These results further show that funding in Ladysmith is still a major challenge.

Concerning the education levels of the participants, the descriptive statistics results revealed that on average the black community of Ladysmith is educated. The results show that $1.6 \%$ only passed Grade 7, $1.1 \%$ passed Grade 8, $0.4 \%$ passed Grade 9, 1.8\% passed Grade 10, 2.9\% passed Grade 11 and $33.8 \%$ passed their matric. Furthermore, the results showed that $5.6 \%$ of the total sample had college higher certificates, $12.7 \%$ had diplomas, 30.2\% had degrees, $9.1 \%$ had honours degrees, $0.4 \%$ had their master's degree and lastly $0.4 \%$ had PhDs. It is also worth noting that a majority of the female participants had completed their matric, accounting for $34 \%$, followed by $30.2 \%$ of those who had completed their bachelor's degrees. In a similar trend to the female participants, a majority of male participants had completed their matric, accounting for $33.6 \%$, followed by $30.3 \%$ with a bachelor's degree. The results also depict that in the total sample, only two males had PhDs.

\section{Interpretation of results: Table $\mathbf{3}$}

All the variables, except for per capita household income, were statistically significant, indicating a meaningful relationship. Detailed reporting on the findings of this study is presented in the following.

Age has a positive coefficient that is statistically significant at $1 \%$. These results show a positive and meaningful relationship between self-employment and age. The coefficient may be loosely interpreted as suggesting that as the person grows older by a year, it results in an increase in the odds in favour of him or her becoming self-employed by 1.0327 or about $3.2 \%$

Gender has a positive coefficient that is statistically significant at $5 \%$. The coefficients show a positive and meaningful 
TABLE 2: Descriptive statistics.

\begin{tabular}{|c|c|c|c|c|c|c|}
\hline \multirow[t]{3}{*}{ Variable } & \multicolumn{4}{|c|}{ Entrepreneur involvement by gender } & \multicolumn{2}{|c|}{ Total } \\
\hline & \multicolumn{2}{|c|}{ Female } & \multicolumn{2}{|c|}{ Male } & \multirow[b]{2}{*}{ Frequency $(n)$} & \multirow[b]{2}{*}{ Percentage $(\%)$} \\
\hline & Frequency $(n)$ & Percentage (\%) & Frequency $(n)$ & Percentage (\%) & & \\
\hline \multicolumn{7}{|l|}{ Occupation } \\
\hline Self-employed & - & - & - & - & 151 & 33.6 \\
\hline Employed & - & - & - & - & 299 & 66.4 \\
\hline \multicolumn{7}{|l|}{ Gender } \\
\hline Employed & 154 & 51.5 & 145 & 48.5 & 299 & 66.4 \\
\hline Self-employed & 61 & 40.4 & 90 & 59.6 & 151 & 33.6 \\
\hline \multicolumn{7}{|l|}{ Age } \\
\hline$\leq 30$ years & 73 & 34.0 & 79 & 33.6 & 152 & 33.8 \\
\hline $31-38$ years & 81 & 37.7 & 68 & 28.9 & 149 & 33.1 \\
\hline$\geq 39$ years & 61 & 28.4 & 88 & 37.4 & 149 & 33.1 \\
\hline \multicolumn{7}{|l|}{ Marital status } \\
\hline Married & 85 & 39.5 & 112 & 47.7 & 197 & 43.8 \\
\hline \multicolumn{7}{|c|}{ Household income per capita } \\
\hline RO-R800 & - & - & 3 & 1.3 & 3 & 0.7 \\
\hline R800-R1500 & 9 & 4.2 & 2 & 0.9 & 11 & 2.4 \\
\hline R1500-R3000 & 1 & 0.5 & 9 & 3.8 & 10 & 2.2 \\
\hline R3000-R5000 & 43 & 20.0 & 46 & 19.6 & 89 & 19.8 \\
\hline R5000-R10 000 & 59 & 27.4 & 56 & 23.8 & 115 & 25.6 \\
\hline R10 000-R20 000 & 71 & 33.0 & 76 & 32.3 & 147 & 32.7 \\
\hline R20 000+ & 32 & 14.9 & 43 & 18.3 & 75 & 16.7 \\
\hline \multicolumn{7}{|l|}{ Family business background } \\
\hline Yes & 158 & 73.5 & 151 & 64.3 & 309 & 68.7 \\
\hline No & 57 & 26.5 & 84 & 35.7 & 141 & 31.3 \\
\hline \multicolumn{7}{|l|}{ Access to finance } \\
\hline Yes & 42 & 19.5 & 51 & 21.7 & 93 & 20.7 \\
\hline No & 173 & 80.5 & 184 & 78.3 & 357 & 79.3 \\
\hline Grade 8 & 5 & 2.3 & 38 & 0.0 & 5 & 1.1 \\
\hline Grade 9 & 0 & 0.0 & 2 & 0.9 & 2 & 0.4 \\
\hline Grade 10 & 2 & 0.9 & 6 & 2.6 & 8 & 1.8 \\
\hline Grade 11 & 8 & 3.7 & 5 & 2.1 & 13 & 2.9 \\
\hline Grade 12 (Matric) & 73 & 34.0 & 79 & 33.6 & 152 & 33.8 \\
\hline Higher certificate (13) & 12 & 5.6 & 13 & 5.5 & 25 & 5.6 \\
\hline Diploma (14) & 29 & 13.5 & 28 & 11.9 & 57 & 12.7 \\
\hline Degree (15) & 65 & 30.2 & 71 & 30.2 & 136 & 30.2 \\
\hline Honours degree (16) & 18 & 8.4 & 23 & 9.8 & 41 & 9.1 \\
\hline Master's degree (17) & 1 & 0.5 & 1 & 0.4 & 2 & 0.4 \\
\hline $\mathrm{PhD}(18)$ & 0 & 0.0 & 2 & 0.9 & 2 & 0.4 \\
\hline
\end{tabular}

relationship between gender and self-employment. The coefficients of gender were 0.453291 , which simply suggests that $\exp (\beta)=\exp (0.453291) \approx 1.573482$. In other words, being a female increases the odds of being self-employed by 1.573482 or about $57.35 \%$. According to these results, females are more likely to be self-employed than men. These findings confirm the findings of Blanchflower (2000), who asserted that mothers were more likely to use self-employment to balance work and family life.

As per the research findings, marital status has a negative coefficient that is statistically significant at $1 \%$. The coefficients show a negative relationship between marital status and self-employment. The coefficients of marital status were -0.811096 , which simply suggests that $\exp (\beta)=\exp (-0.811096)$ $\approx 0.44437$. In other words, being single decreases the chances (odds) of being self-employed by 0.44437 or about $55.56 \%$.
This suggests that single people are more likely to become gainfully employed than being self-employed. These results confirm the findings of Taniguchi (2002), who also found that married people are more inclined to become self-employed than single people. The reasoning for this was that married people have acquired enough assets or capital to start a business and also use self-employment to balance career and family responsibilities.

Education has a positive coefficient that is statistically significant at $10 \%$. The coefficients of education were 0.122721 , which simply suggests that that $\exp (\beta)=$ $\exp (0.122721) \approx 1.1306$. In other words, an additional year of education increases the possibility (odds) of being selfemployed by 1.1306 or about $13.07 \%$. These results suggest that the higher the education levels, the more likely an individual is to become self-employed. According to Arum 
and Muller (2004), education enhances people's interpersonal, management and business skills. Education provides people with skills needed to run and manage a successful business (Smit et al. 2007). Furthermore, Koellinger (2008) asserts that higher education levels enable individuals to spot gaps in the market; hence they are able to start viable businesses.

Family business background has a positive coefficient that is statistically significant. This coefficient depicts a positive and meaningful relationship between self-employment and family business background. The coefficients of family business background were 0.8991859 , which suggests that $\exp (\beta)=\exp (0.8991859) \approx 2.4576$. According to these results, when a person has a family business background, the odds of that person becoming self-employed increase by 2.4576 or about $146 \%$. This is true because the transfer of capital, knowledge, information and contacts the parents have already established in the business sector is

TABLE 3a: Logistic regression results.

\begin{tabular}{lccccc}
\hline $\begin{array}{l}\text { Dependent } \\
\text { variable }\end{array}$ & Coefficient & $\begin{array}{l}\text { Standard } \\
\text { error }\end{array}$ & $z$-stat & Prob. & Odds ratio \\
\hline AGE & 0.032 & 0.012 & $2.583 * * *$ & 0.009 & 1.033 \\
GEN & 0.453 & 0.217 & $2.093^{* *}$ & 0.036 & 1.573 \\
MAR & -0.811 & 0.257 & $-3.154 * * *$ & 0.002 & 0.444 \\
EDU & 0.123 & 0.061 & $1.997 * *$ & 0.046 & 1.131 \\
HIP & -0.077 & 0.100 & -0.766 & 0.444 & 2.458 \\
FBB & 0.899 & 0.232 & $3.845 * * *$ & 0.000 & 4.971 \\
AC & 1.604 & 0.329 & $4.868 * * *$ & 0.000 & 4.971 \\
RIS & -0.170 & 0.098 & $-1.731 *$ & 0.084 & 1.185 \\
\hline C & -2.415 & 1.026 & $-2.353 * * *$ & 0.017 & -0.911 \\
\hline
\end{tabular}

AGE, Age; GEN, Gender; MAR, Marital status; EDU, Education; HIP, Household income per capita; FBB, Family business background; AC, Access to finance; RIS, Risk propensities; C, Constant.

TABLE 3b: Logistic regression results.

\begin{tabular}{lc}
\hline Variable & Result \\
\hline McFadden $R$-squared & 0.105 \\
SD dependent var & 0.473 \\
Akaike info criterion & 1.182 \\
Schwarz criterion & 1.264 \\
Hannan-Quinn criterion & 1.215 \\
Restricted deviance & 574.24 \\
H-L statistic & 8.501 \\
Andrews statistic & 11.929 \\
F-statistic & 6.988 \\
Chi-square & 48.915 \\
LR statistic & 60.237 \\
Prob (LR statistic) & 0.000 \\
Mean dependent var & 0.664 \\
SE of regression & 0.447 \\
Sum squared residual & 88.087 \\
Log likelihood & -257.001 \\
Deviance & 514.002 \\
Restr. log likelihood & -287.120 \\
Avg. log likelihood & -0.571 \\
Prob. chi-sq (8) & 0.386 \\
Prob. chi-sq (10) & 0.290 \\
Probability & 0.000 \\
Probability & 0.000 \\
\hline SD standard & \\
\hline
\end{tabular}

SD, standard deviation; SE, standard error; H-L, Hosmer-Lemeshow; LR, Log likelihood; var, varience; resid, residual; restr., restricted; avg., average log likelihood; prob., probability chi-sq, chi-squared easy (Lee \& Rendalli 2001). The contacts open doors that would have been difficult to open, and capital is easily accessed (Yoon 1997).

Access to finance has a positive coefficient that is statistically significant. This coefficient depicts a very strong and meaningful relationship between selfemployment and access to finance. The coefficient of access to finance was 1.603572, which suggests that $\exp (\beta)=$ $\exp (1.603572) \approx 4.9707$. These results suggest that an increased funding opportunity increases the odds of a person becoming self-employed by 4.9707 or about $397 \%$. This is true because one of the key challenges faced by the self-employed is access to finance. Finance hinders potential entrepreneurs to start their businesses because finance is needed to buy equipment and cover operational costs; hence increased funding opportunities eliminate all finance challenges.

With regards to risk propensities, the assumed relationship is that people who are not risk averse are more likely to be self-employed. This is because they are not afraid to take risks. By definition, the self-employed are people who take calculated risks; however, the results showed an interesting relationship. The coefficients of the risk propensity showed a negative but significant relationship between self-employment and risk propensities.

The coefficients of risk propensities were -0.169584 , which suggests that $\exp (\beta)=\exp (-0.169584) \approx 0.84402$. These results show that if a person is risk averse, the odds of that person becoming self-employed decreases by 0.84402 or about $15.6 \%$. This simply means that people who are afraid of risk are more likely to become gainfully employed.

\section{Diagnostic tests}

The diagnostic tests that were employed in this study - as thoroughly explained in the methodology - are the HL test, which assessed the goodness of fit, and the Wald test statistic, which served as a $T$-statistic for the logistic regression model.

\section{Hosmer-Lemeshow test}

The HL test results (Table 3) compared the predicted values against the actual values of the dependent variable. The results of the test showed a HL value of 8.5009 and a probability of 0.3861 , indicating a good model of fit. Simply put, these results confirm that the model employed in this study is correctly specified and it adequately fit the data.

The HL test is supported by the Andrew statistic, which depicts a value of 11.92 and $p$-value of 0.2898 , confirming that the model does fit the data. This gives an assurance that the results from this study are reliable and can be trusted for policy consideration. 
Furthermore, the McFadden pseudo R-squared test statistic of 10.5 (see Table 3) corroborates both the HL and the Andrew statistics, which suggests the model has a reasonably good fit.

\section{Wald statistic test}

The Wald statistic test was employed to assess the significance of coefficients in the model. With reference to Table 3, the Wald statistic test in this study as 6.987 and the probability was 0.0000 , suggesting that the model has predictive capacity. The variables included in this model will be able to predict a meaningful relationship of interest. Since the model is significant, this study therefore rejects the null hypothesis that the variables are equal to zero.

\section{Conclusion}

Following the unprecedented increase in the self-employment rates in South Africa, the study investigated the determinants of self-employment within the black community in Ladysmith. After considering factors such as age, gender, marital status, family business background, household income per capita, education levels, access to finance and risk propensity, the regression results of this study showed that all factors except the household income per capita were statistically significant, indicating a meaningful and positive relationship.

The results showed that being a female increases the possibility of being self-employed by $57.35 \%$, therefore suggesting that self-employment support programmes can be used to not only to involve women in the mainstream economy through entrepreneurial activities but also to promote the development agenda of marginalised communities.

The results have shown that educated individuals as well as adults are the most likely entrepreneurs among black people; hence support programmes to promote selfemployment must include business skills development at school and tertiary levels, but should also target adults in the form of community-based adult business education short courses, access to finance guidance, together with financial life skills programmes. A combination of skills development and guidance-based access to finance to the targeted groups involving women, the young adults at schools and tertiary institutions and entrepreneurial adults are likely to reap significant outcomes.

\section{Acknowledgements Competing interests}

The authors declare that they have no financial or personal relationships that may have inappropriately influenced them in writing this article.

\section{Authors' contributions}

The study was conducted by S.N.K. Under the supervision of I.K., S.N.K. was responsible for the project design, planning, fieldwork, data analysis and write-up. I.K. provided guidance to ensure that the article is completed timely.

\section{References}

Al-Ghamdi, A.S. 2001, 'Using logistic regression to estimate the influence of accident factors on accident severity', Pergamon 34, 729-741.

Allen, E., Elam, N., Langowitz, N. \& Dean, M., 2008, Global entrepreneurship monitor report on women and entrepreneurship, Global Entrepreneurship Research Association (GERA), Hanover, MA. s.I.

Arenius, P. \& Minniti, M., 2005. 'Perceptual variable and nascent entrepreneurship', Small Business Economics 24, 233-247. https://doi.org/10.1007/s11187-005-1984-x

Arum, R. \& Müller, W., 2004, There emergence of self-employment a comparative study of self-employment dynamics and social inequality, Princeton University Press, Princeton, NJ, p. 480.

Banerjee, A., Duflo, E. \& Glennerster, D.K., 2010, 'Improving immunization coverage in rural India: A clustered randomized controlled evaluation of immunization campaigns with and without incentives', viewed n.d., from http://economics.mit. edu/files/5578

Bargain, O. \& Kwenda, P., 2009, The informal sector wage gap: New evidence using quantile estimations on panel data, IZA, Issue IZA DP No. 4286, Bonn, German.

Blanchflower, D.G., 2000, 'Self-employment in OECD countries', Labour Economics 7, 471-505. https://doi.org/10.1016/S0927-5371(00)00011-7

Bosma, N. \& Levie, J., 2010, Global entrepreneurship monitor 2009 report, GEM, s.I.

Budig, M.J., 2006. 'Gender, self-employment, and earnings the interlocking structures of family and professional status', Gender \& Society 20, 725-753. https://doi. org/10.1177/0891243206293232

Butler, J. \& Herring, C., 1991, 'Ethnicity and entrepreneurship in America: Toward an explanation of racial and ethnic group variations in self-employment', SAGE Journals 34, 79-94. https://doi.org/10.2307/1389144

Companies and Intellectual Property Commission (CIPC), 2016, Companies intellectual property commission annual report, CIPC, Pretoria.

Clark, K. \& Drinkwater, S., 2000, 'Pushed out or pulled in? Self-employment among ethnic minorities in England and Wales', Elsevier 7, 6003-6628.

Eddleston, K.A. \& Powell, G., 2012, 'Nurturing entrepreneurs' work-family balance: A gendered perspective', Entrepreneurship Theory and Practise 36, 513-514.

Elert, N., Andersson, F. \& Wennberg, K., 2015, The Impact of entrepreneurship education in high school on long-term entrepreneurial performance, Econstor, Issue IFN Working Paper No. 1063, 2015.

Emnambithi Ladysmith Municipality (ELM), 2015, Emnambithi/Ladysmith Integrated Development Plan, Ennambithi/Ladysmith Municipality White Paper.

Fairlie, R.W. \& Meyer, B.D., 1996, 'Ethnic and racial self-employment differences and possible explanations', Journal of Human Resources 31, 757-793. https://doi. org/10.2307/146146

GEM, 2012, Global entrepreneurship monitor, GEM, s.I.

GEM, 2016. Global entrepreneurship monitor, Global Entrepreneurship Monitor, s.l.

Georgellis, Y. \& Wall, H., 2005, 'Gender differences in self-employment', International Review of Applied Economics 19, 321-342. https://doi.org/10.1080/02692170 500119854

Goduscheit, R.C., 2011, State of the art in entrepreneurship research: A policy-oriented review with particular emphasis on the gender perspective and the Norwegian context, Damvad, Copenhagen, 23 October.

Gordon, S.L., 2010, Gender differences in Self-employment characteristics in Post-Apartheid South Africa: A detailed analysis of the self-employed, Durban, KwaZulu-Natal.

Hamilton, B.H., 2000, 'Does entrepreneurship pay? An empirical analysis of the returns to self-employment', Journal of Political Economy 108, 604-631.

Halvorsen, C.J. \& Morrow-Howell, N., 2017, 'A conceptual framework on selfemployment in later life: Toward a research agenda', Work, Aging and Retirement 3(4), 313-324, https://doi.org/10.1093/workar/waw031

Henley, A., 2009, Switching costs and occupational transition into self-employment, Institute for the Study of Labor, Bonn, Germany.

Herrington, M., Kew, J. \& Kew, P., 2009, Tracking entrepreneurship in South Africa: A GEM perspective, Global Entrepreneurship Monitor, Graduate School of Business, University of Cape Town.

Humphries, J.E., 2017. The Causes and Consequences of Self-Employment over the Life Cycle. Mimeo, University of Chicago.

Joona, P.A. \& Wadensjö, E., 2011, 'The best and the brightest or the least successful? Self-employment entry among male wage-earners in Sweden', Small Business Economics 40(1), 155-172. https://doi.org/10.1007/s11187-011-9365-0

Kautonen, T., Luoto, S. \& Tornikoski, E.T., 2010, 'Influence of work history on entrepreneurial intentions in 'prime age' and 'third age': A preliminary study',
International Small Business Journal 28(6), 583-601. https://doi.org/10.1177/ 0266242610368592 
Kibler, E., Wainwright, T., Kautonen, T. \& Blackburn, R., 2015, 'Can social exclusion against "older entrepreneurs" be managed?', Journal of Small Business Management 53, 193-208.

Koellinger, P., 2008, 'Why are some entrepreneurs more innovative than others?', Small Business Economics 31, 21.https://doi.org/10.1007/s11187-008-9107-0

Ladysmith Chamber of Commerce (LCC), 2016, Ladysmith chamber of commerce brochure, s.n, s.l.

Lee, M.A. \& Rendalli, M.S., 2001, 'Self-employment disadvantage in the working lives of blacks and females', Population Research and Policy Review 20(4), 291-320.

Livanos, I., 2009, 'What determines self-employment? A comparative study', Applied Economics Letters 16, 227-232. https://doi.org/10.1023/A:1011887013195

Maas, G. \& Herrington, M., 2006. Global entrepreneurship monitor: South African report, Graduate School of Business, University of Cape Town, Cape Town.

Minola, T., Criaco, G. \& Obschonka, M., 2015, 'Age, culture, and self-employment motivation', Small Bus Econ 46, 187-213. https://doi.org/10.1007/s11187-015-9685-6

Organisation for Economic Co-operation and Development (OECD), 2013, Government at a glance 2013, OECD Publishing, Paris, France.

Orth, U., Trzesniewski, K.H. \& Robins, R.W., 2010, 'Self-esteem development from young adulthood to old age: A cohort-sequential longitudinal study', Journal of Personality and Social Psychology 98(4), 645. https://doi.org/10.1037/a0018769

Parker, S.C., 2005, 'Explaining regional variations in entrepreneurship as multiple equilibria', Journal of Regional Science 45(4), 829-850. https://doi.org/10.1111/ j.0022-4146.2005.00394.x

Preisendörfer, P., Bitz, A. \& Bezuidenhout, F., 2011, In search of black entrepreneurship: Why is there a lack of entrepreneurial activity among the black population in South Africa?, s.n, South Africa.

Ruffer, T. \& Knight, J., 2007, Informal sector labor markets in developing countries, University of Oxford.
South African Revenue Services (SARS), 2015/16. South African Revenue Services, s.I.: SARS.

Schjoedt, L., Renko, M. \& Shaver, K.G., 2014, 'Looking into the future: Valid multipleand single-item measures in entrepreneurship research. Handbook of research methods and applications', Entrepreneurship and Small Business 112-135.

Smit PJ, de Cronje, G.J., Brevis, T. \& Vrba, M.J., 2007, Management principles: A contemporary edition for Africa, Juta and Co Itd, Cape Town.

Statistics South Africa (StatsSA), 2011, 2011 Census, StatsSA, Pretoria.

StatsSA, 2015/16, Statistics South African annual report, Statistics South African, Pretoria.

StatsSA, 2017, Work and labour force, Statistics South Africa, Pretoria.

Stefanovic, S. \& Stosic, D., 2012, 'Age and education as determinants of entrepreneurship', 9(179081), 327-339.

Steier, L., 2007, 'New venture creation and organization: A familial sub-narrative', Journal of Business Research 60, 1099-1107. https://doi.org/10.1016/j.jbusres.2006.12.017

Taniguchi, H., 2002, 'Determinants of women's entry into self-employment', Socia Science Quarterly 3, 875-893. https://doi.org/10.1111/1540-6237.00119

Taylor, M.P., 1999, 'Survival of the fittest? An analysis of self-employment duration in Britain', Economic Journal 109, C140-C155. https://doi.org/10.1111/14680297.00422

Unger, J.M., Rauch, A., Frese, M. \& Rosenbusch, N., 2011, 'Human capital and entrepreneurial success: A meta-analytical review', Journal of Business Venturing 26(3), 341-358. https://doi.org/10.1016/j.jbusvent.2009.09.004

Van Praag, M., van Witteloostuijn, A. \& van der Sluis, J., 2013, 'The higher returns to formal education for entrepreneurs versus employees', Small Business Economics 40(2), 375-396. https://doi.org/10.1007/s11187-012-9443-y

Yoon, I.-J., 1997, On my own: Korean businesses and race relations in America, University of Chicago Press. 